\title{
Acetone diethyl acetal
}

\author{
提案者 谷本重 夫, 今津昌 久 \\ (京都大学化学研究所) (広栄化学工業株式会社)

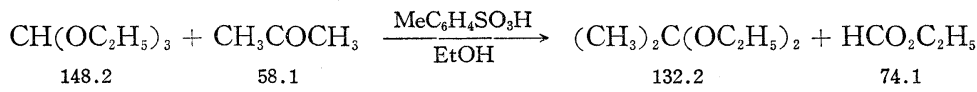

I. 製 法

還流冷却器を付けた $1 \ell$ ナス型フラスコにエタノール $232 \mathrm{~g}(5.04 \mathrm{~mol})$, ethyl orthoformate $156 \mathrm{~g}(1.05 \mathrm{~mol})$, acetone（注意 1) $52 \mathrm{~g}(0.90 \mathrm{~mol}$ ) および無水の $p$-トルエンスルホン酸（注意 2) $0.3 \mathrm{~g}$ を入れ，内容が淡褐色になる まで 30 45 分還流煮沸する。ただちに金属ナトリウム $0.3 \mathrm{~g}$ からつくったナトリウムエチラートのエタノール溶液を 加え, さらに濃アンモニア水 $5 \sim 10 \mathrm{~m} l$ を加えてよく振る（注意 3 ）。つぎにこれを水（注意 4 ）約 $800 \mathrm{ml}$ にかきまぜ ながら加える。分離した油層を蒸留して bp 107〜 $117^{\circ} \mathrm{C}$ の留分をとる。このときの初留に適当量の炭酸力リウムと塩 化カルシウムの混合物を加えてからよく振り（注意 5), 口過してロ液を蒸留して 前と同じ沸点範囲のものを 捕集する (注意 6)。こうして集めた bp $107 \sim 117^{\circ} \mathrm{C}$ の留分に少量の炭酸カリウムと塩化カルシウムの混合物を加えて乾燥し， 再蒸留して bp $110 \sim 116^{\circ} \mathrm{C}$ (主留分の bp $113^{\circ} \mathrm{C}$ ) の留分をとる。収率 $74 \%$ 。

\section{II. 注意 事項}

（1）無水の炭酸カリウムを acetone に加えてよく振り，ロ過したものを用いる。

（2）市販の $p$-トルエンスルホン酸は結晶水を有するので，減圧下 $100^{\circ} \mathrm{C}$ に加熱して無水になったものを用いる。

（3）ナトリウムエチラートを加えた時点で十分アルカリ性であるが，アンモニア水を加えてこれを完全にする。

（4）Hurd ら は反応後, 反応混合物を中和してから蒸留水に加えているが, 往々にして目的物が加水分解をおこ し油層を分離しない。十分アルカリ性にしておけば水道水に加えても常に油層が分離する。

（5）塩化カルシウムで混入しているエタノールを除去するのが目的であり，常にアルカリ性に保つため炭酸カリウ ムを混ぜて用いる。

（6）ここにおける初留に再び塩化カルシウムと炭酸カリウムの混合物を加えてよく振ってから蒸留すると bp 107 $117^{\circ} \mathrm{C}$ の留分がさらに少量えられ，全体の収率が向上する。しかし，このようなことを繰り返しても手数である。

\section{III. 性質}

特有の芳香を有する軽い液体で, 滅菌用塩素の入っている水道水に加える位でも瞬間的に加水分解されるが, アルカ リ性では非常に安定である。

\section{IV. 本法の利点}

acetone diethyl acetal を合成するのにテトラエトキシシランから出発する方法"2), および酢酸イソプロペニルから出 発する方法 ${ }^{3)}$ がある。前者は収率はよいが原料が高価であり，後者は酸化水銀 (II) を触媒に用いた上に，収率まで劣 る。本法は Hurd ら ${ }^{1)}$ 開発した方法そのままに，新しく考案した後処理法を付けたしたものである。すなわち，アル カリ性である限り安定であるといら特性を考慮に入れ，混入しているエタノールを塩化カルシウムでとり去ることが効 果的といえる。

引用文献

1) C.D. Hurd, M.A. Pollack, J. Am. Chem. Soc. 601905 (1938)

2) I.N. Nazarov, S.M. Makin, BK. Kruptsov, Doklady. Akad Nauk, 117823 (1957) ; C.A. 528036 (1958)

3) W.J. Croxall, F.J. Glavis, H.T. Neher, J. Chem. Soc. 702805 (1948) 